\title{
Historic Open Space: The Identity of [Padang] Merdeka Square, Kuala Lumpur, Malaysia
}

\author{
Nadiyanti Mat Nayan ${ }^{1}$, David S Jones ${ }^{2}$, Suriati Ahmad ${ }^{1}$
}

1Department of Landscape Architecture, Faculty of Architecture, Planning and Surveying, Universiti Teknologi MARA (UiTM) Perak Branch, Seri Iskandar 32610, Malaysia

${ }^{2} \mathrm{School}$ of Architecture \& Built Environment,

Deakin University - Geelong Waterfront Campus, Victoria 3220, Australia

nadiy028@uitm.edu.my, david.jones@deakin.edu.au, suria564@uitm.edu.my

\begin{abstract}
In 1880, when the British moved their Federated Malay States administrative centre to Kuala Lumpur, the Padang quickly became a symbol of British economic and administrative colonisation, and a nucleus of the socio-cultural development of Kuala Lumpur. This paper discusses the layers of history, symbolism and cultural values that the Padang contributes to the socio-cultural tapestry of both Kuala Lumpur and Malaysia, and the lack of relevant planning and heritage measures to conserve these attributes and characteristics. The conclusions offer avenues to engage with pre- and post-colonisation that enable re-making and the conservation of the iconic space of Kuala Lumpur.
\end{abstract}

Keywords: Urban open space; Merdeka Square; Kuala Lumpur City Hall; National Heritage Act 2005

eISSN: 2398-4295 @ 2019. The Authors. Published for AMER, ABRA \& cE-Bs by e-International Publishing House, Ltd., UK. This is an open access article under the CC BY-NC-ND license (http://creativecommons.org/licenses/by$n c-n d / 4.0 /$ ). Peer-review under responsibility of AMER (Association of Malaysian Environment-Behaviour Researchers), ABRA (Association of Behavioural Researchers on Asians) and $c E-B s$ (Centre for EnvironmentBehaviour Studies), Faculty of Architecture, Planning \& Surveying, Universiti Teknologi MARA, Malaysia.

DOI: http://dx.doi.org/10.21834/ajbes.v4i17.182 


\subsection{Introduction}

Recently, the conservation of heritage buildings has been numerically growing (Gholitabar, Alipour, \& Costa, 2018, p. 3). Additionally, the number of designated heritage buildings globally has expanded exponentially since the establishment of the World Heritage List regime following the Second World War. Heritage buildings have always being portrayed as the cultural imagery of the cities; its 'trademarks' (Gholitabar et al., 2018, p. 4). Hence, the existence of a non-building area, or open space, is often overlooked even though these places can be an integral part of a nation's history. Therefore, there is increasingly an inequity between designated heritage buildings and non-designated or recognized spaces.

Historic heritage places, spaces, sites or areas need to be treated as being just as important as heritage buildings as these physically-created places can be exemplar of "demonstrating ways of life, customs, land use or designs", and therefore contribute to the heritage values and significance of a nation's history (Australian Heritage Commission, 2000; Environment Foundation, 2017). The understanding of these historic space are important as these spaces represent different characters and values (Nayan, 2017, p. 65).

In Malaysia, until December 2018, only fifty-seven items have been gazetted as 'National Heritage' under the Malaysian National Heritage Act 2005 (Act 645). Forty-six of these items are buildings, three are archaeological sites, and eight are natural sites. Additionally, under this Heritage List, some 189 places are listed with 183 being buildings, four being archaeological sites, and two being places of natural heritage. Unfortunately, historic squares, open spaces or gardens are not included in the List. If development trends continue in Malaysia, these significant spaces or areas will most likely vanish in this the era of 'progress' and modernity.

A classic example is Padang Banda Hilir (now known as Dataran Pahlawan), at Banda Hilir in Melaka State in Malaysia. Once an important place in the history of Malaysia, Padang Banda Hilir was where the independence of the Federation of Malaya was officially announced in 1956. More than 100,000 people witnessed on 31 August 1957 this momentous event in the creating a new nation. Padang Banda Hilir has now been sacrificed to make way for new development. As discussed by Bachek (2014), the unsympathetic intrusion of new developments is well known in Malaysia as compromising Malaysian place conservation efforts and the 'story' of Malaysia (Bachek, Zainudin, \& Haron, 2014, pp. 1-4). To ensure that a historic heritage place is equally protected, this space should be afforded the same conservation legal protection afforded to heritage-listed buildings. There is no one answer on conserving heritage or historic sites, but with adequate and consistent process the safeguarding of these valuable heritage are possible (Historic England, 2015, p. 44; Nayan, 2017, p. 66)

The Padang Merdeka, or Merdeka Square, in Kuala Lumpur, is one of the significant spaces that lack a heritage designated; an essential part of Malaysia's 'story', there is no heritage concern about ensuring the continuity of this 'story'. Following the chronology of the announcement of Malaysian independence at Padang Banda Hilir, the Padang was the place where the Malaysian flag was first raised. While the flag ceremony was one of the most memorable events for the majority of Malaysians, the heritage layers of the Padang have continuously evolved since the existence of Kuala Lumpur in the early 1850s. The Padang 
has today become an important venue and a witness to many historical events in Malaysia from the 1850s.

\subsection{Literature Review}

The roles and functions of Padang started with the formation of Kuala Lumpur. From the literature, the origins of Kuala Lumpur lie at the confluence of two rivers, the Gombak and Klang rivers. It is believed that the origins of the settlement date to 1850. Kuala Lumpur's history started to change when tin was discovered in Ampang, two miles from Kuala Lumpur in 1857. Starting from a Malay settlement, it had become a multiracial town with the Chinese, British, and Eurasians. Progressively, Padang had also received a positive impact from the development (Fig. 1). Today, it has evolved from a swampy land into an important venue for Malaysia.

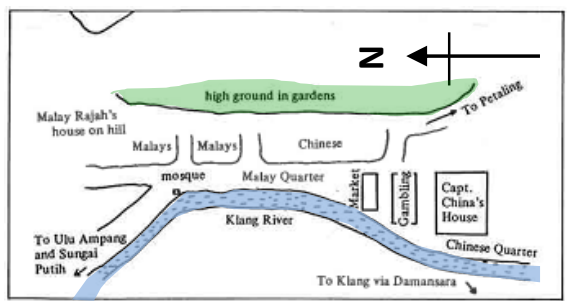

Fig.1. Swettenham's sketch of Kuala Lumpur in 1875 is the earliest map of Kuala Lumpur. Padang was stated in the map as the 'high ground in gardens'.

Source: (From Sir Frank Swettenham's Malayan Journals in Gullick, 1998, p. 5).

\subsection{Social and cultural background of the Padang}

The history of the Padang started as an uneven, swampy and unoccupied area. Following British colonisation, in 1880 the area it was filled with vegetable gardens and fruit trees owned by members of the Chinese community. A line of attap huts stood on the edge of the vegetable patches, and the northern and southern ends of the Padang sloped away into swampy areas.

In the early 1890s, after the British Resident and his officers were relocated from Klang to Kuala Lumpur, the vegetable gardens were cleared to make way for a military and police parade ground. This is why the Padang was known as the "Police Parade Ground" for many years. For the European community, the Padang was the centre of social life. Located spatial centrally, it was encircled by several distinctive and architecturally prominent buildings, including the Selangor Club House, St Mary's Church, the Chartered Bank, and the Bangunan Sultan Abdul Samad. It thus became the nucleus for Kuala Lumpur's communal activity, and thus the pivot of Peninsula Malaya governance.

Upkeep and improvements of the Padang commenced from 1890 onwards under the Kuala Lumpur Municipal Council management. The Padang land was flattened, levelled, and drained. This was the beginning of the modern era for the Padang. Whilst functioning as a communal space, the Padang also became the centre of all formal sporting games, including 
cricket. The Padang was also the scene of major public occasions, including the celebration of Queen Victoria's Jubilee in 1897. The roles and importance of the Padang have evolved since the 1800s. As narrated by the Kuala Lumpur Municipal Council (1959), "Kuala Lumpur would not be Kuala Lumpur without its ornate row of Government buildings facing on to the Padang"(The Kuala Lumpur Municipal Council, 1959, p. 68). Hence, this statement evidences the importance of the Padang as being an integral part of Kuala Lumpur's identity.

\subsection{Padang as the cultural nucleus of the city}

The Padang witnessed the early era of Malaya; the era of tin mining industries, the colonial invasion, Independence day, until the modernization of Kuala Lumpur. These roles, as a cultural centre, have evolved with the development of Kuala Lumpur. However, the space only became a communal cultural area from early 1884. In 1884 the Selangor Club House was constructed on the northern end of the Padang. All events of the Club, especially cricket matches, were thereafter held on the Padang. The Club House and the Padang were built specifically for the social and recreational needs of the expanding expatriate community in Kuala Lumpur (Gullick, 1998, p. 67; Lubis, 2018, p. 35; Yeang, 1992, p. 20). (See Fig. 2(a) and 2(b)). It became the centre of all games, major public ceremonies, gathering areas, and was complemented with a prominent colonial pavilion, bandstand and a fountain for the leisure purposes.

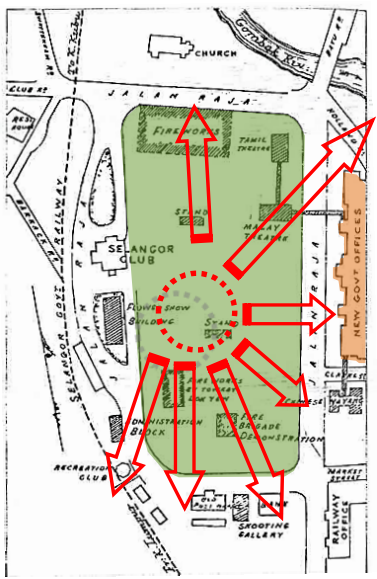

(a)

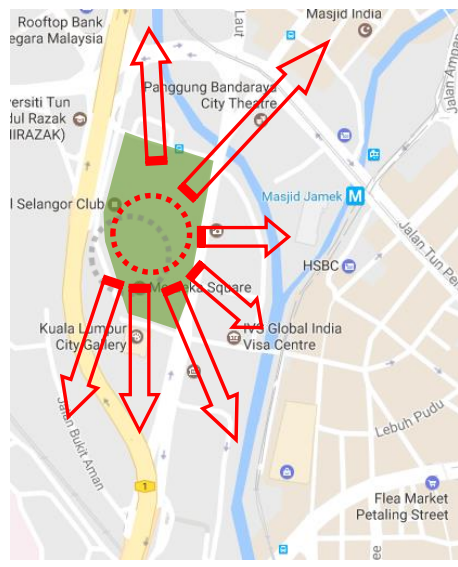

(b)

Fig. 2. (a) The Padang (Merdeka Square) and the government buildings in June 1897; (b) The Padang and the buildings in 2019.

Source: Author's drawing adapted from Selangor Journal, 25 June 1897, in Gullick, 1998, p. 46; Google Maps, 2019.

The Padang was no longer just a "Police Parade Ground". It became the centre of the European quarters of Kuala Lumpur (Gullick, 2007, p. 1; The Kuala Lumpur Municipal 
Council, 1959, pp. 84-85). "The government servants living on the hills behind the Club converged there [the Padang] in the evenings and weekends for their stengahs or tiffins and dinners" [sic.] (Nui, 1997, p. 21). During its early development the Padang could only be accessed by certain groups in Kuala Lumpur's society thus being expressionally a hierarchically signified space (King, 2008, p. 186; Southgate \& Bracken, 2014, p. 15).

Despite its name, until now, it remains one of the most significant focal points for important events in Malaysia, especially for the yearly celebration of Malaysia's Independence Day. With over 140 years of layers of history, this space should be protected equally to the surrounding heritage listed buildings. As mentioned by Rudduck (1955), "the sitting and architectural treatment of the principal governmental buildings [of Kuala Lumpur], the landscaping of surrounding areas and their relationship to the planning of the reminder of the town, are matters of the greatest importance" (Rudduck, 1955, p. 71)(See Fig. 3(a) and $3(b))$.

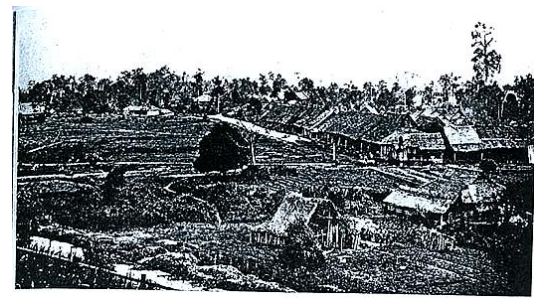

(a)

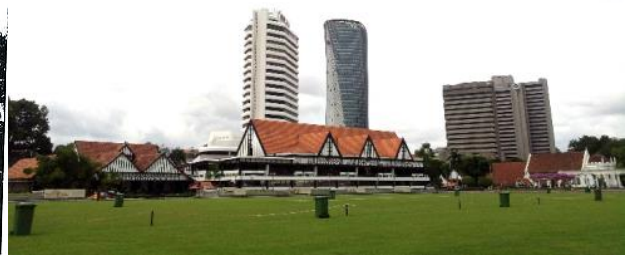

(b)

Fig. 3. (a) The Padang in 1884. On the far side of the Padang was the recently-built first Selangor

Club; (b) The Padang in 2018. The new Selangor Club House in a pseudo-Tudor style. (Sources: (The Kuala Lumpur Municipal Council, 1959, p. 12); Author, 2018)).

\subsection{The Padang nowadays from the perspectives of laws}

The Padang is today known as "Merdeka Square" or "Dataran Merdeka", and it is managed by the Kuala Lumpur City Hall (KLCH). For management purposes, the KLCH implementing management under two important regulatory documents; the Kuala Lumpur Structure Plan 2020 (KLSP2020) and the Draft Kuala Lumpur City Plan 2020 (DKLCP2020). Under the $K L S P 2020$, the Padang area is highlighted as being one of the key tourism resources of Kuala Lumpur under Clause 8.2.3 (b): Cultural Heritage Attractions. The Merdeka Square and the heritage listed buildings that surround it "provide lasting images of the original city" (Kuala Lumpur City Hall, 2000). The KLSP2020, under Clause 13.4.3 (a): Open spaces, mentions the necessities of gazetting the existing open space. Yet, there is no proposed name of the area to be gazetted in the document. Hence, the national heritage list remains vague about this place and the heritage values that the Padang possesses. In addition, the KLSP2020 clearly admits that while conservation programs have been successful, for only a limited number of important heritage buildings, "the maintenance of the character of conservation areas has been less successful" (Section 14.2.3(b): Urban Identity (Conservation Areas), Kuala Lumpur City Hall, 2000).

As a developing City, the issue of maintaining a City's character is urgently needed. 
However, there are no specific frameworks nor guidelines for urban conservation work in this City. In fact, "there is no single body with overall responsibility for devising or implementing urban design policies" for Kuala Lumpur (Section 14.2.3(b): Urban Identity (Conservation Areas), Kuala Lumpur City Hall, 2000). Hence, the future of gazetting an open space as a heritage item might take longer than expected.

Under the DKLCP2020, the Padang is recognised as one key venues on the heritage trail of Kuala Lumpur, under the Strategic Direction 3.3: Promoting International Tourism. Named under 'Heritage Trails 2: Merdeka Square', this recognition indirectly recognises the historic importance of the Padang (Kuala Lumpur City Hall, 2008a, p. 40). Under the Strategic Direction 9.1: Designating Heritage Zone, the Padang is grouped under a 'Primary Heritage Zone'. This zone is a "core area for conservation which is contiguous and contains groups of buildings gazetted under the National Heritage Act 2005" (Kuala Lumpur City Hall, 2008a, p. 129). Development in this zone is controlled to ensure new development does not adversely affect the appearance of the existing buildings including the public open space (Kuala Lumpur City Hall, 2008b, p. 180) (See Fig. 4(a) and 4(b)). However, further subsections in the DKLCP2020 discuss regulations only pertaining to these heritage buildings.

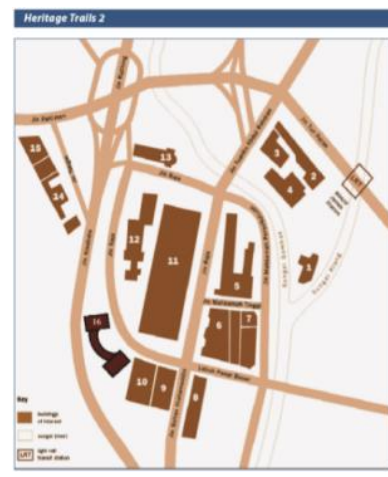

(a)

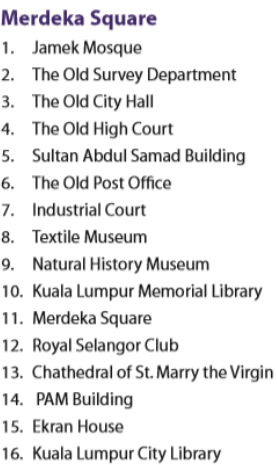

16. Kuala Lumpur City Library

Fig. 4. (a) Merdeka Square Heritage Trail; (b) Merdeka Square under the Primary Heritage Zone surrounded by various categories of heritage buildings.

(Sources: (Kuala Lumpur City Hall, 2008a, 2008b))

Although both documents mention the historic significance of the Padang, unfortunately, there is no detailed framework for conserving or highlighting the Padang as being of national heritage item. The regulatory concentration upon building conservation in both documents has indirectly forgotten the importance of this space as being the aesthetic 'forecourt' and curtilage of these national heritage items.

In respect of the National Heritage Act 2005 (Act 645), this Act clearly states that a "heritage site" is part of the definition of "heritage items". Act 645 also define "areas" as "works of man ... which are of outstanding universal value from the historical, aesthetic, ethnological or anthropological point of view", and that "site" that includes "any area, place, zone, natural 
heritage, monument or building attached to land, archaeological reserve and any land with building, garden, tree or archaeological reserve" (Parliament of Malaysia, 2005, pp. 12-15). In addition, Act 645 defines "zone" as "an area or part of an area for the purpose of preservation and restoration in respect of rural and urban landscapes whether natural or man-made, which embraces any cultural heritage significance" (Parliament of Malaysia, 2005, p. 17). However, after more than 14 years since the Act's gazettal, there is no gazetted "heritage area", no gazette "heritage site" and no gazetted "heritage zone" under the National Heritage List that specifically relates to an open space or to an area. Hence, more action is needed to publicize the history of this area and its historical elements to stakeholders. These approaches need to be aligned to the stated rules and regulations to ensure the safeguarding of the area and its heritage values (Nayan, Khamis, Sakip, \& Rahman, 2018, p. 157).

\subsection{Methodology}

\subsection{Data collection}

This research gathered focused interview perceptions about the importance of the Padang being included on Malaysia's National Heritage List. The study applied semi-structured openended questions through an in-depth interview. To allow for minimal bias, 19 respondents were selected from different organization groups; 4 from government authorities (GA), 4 from state authorities (SA), 4 from the Kuala Lumpur Local Authority (KLLA), 3 from nongovernment organizations (NGO), and 4 from professional practitioners (PP). Although representing different organizations, all participants selected were involved with conservation activities and had knowledge of Malaysia's heritage laws.

\subsection{Data analysis}

This research comprises a case study approach and analysis these interviews by using conversation analysis (CA) and discourse analysis (DA). In analyzing these interviews, CA and DA are the acceptable ways of gaining the data (Mason, 2002, p. 57; Silverman, 2014, p. 236). CA aims to study participants' perceptions, and DA is more concerned with the range of topics. CA and DA emphasize talk and text as data sources.

\subsubsection{Analyzing single case study}

The Padang, or Merdeka Square, was used a case study to assess the application of open space or area in conservation theory and practice in Malaysia. This strategy sought to answer 'how' this heritage space could be gazetted, and 'why' it is important to include the Padang on the Malaysian National Heritage List.

\subsubsection{Analyzing interviews: CA and DA}

For this research, transcriptions of audio recordings for CA employed the Jefferson notation technique. Through Jefferson techniques, interviews were transcribed by using a set of symbols to represent the value of transcripts. With proper notations, it produces a precise transcription for CA. The DA for this research was based upon transcripts of open-ended interviews. The DA was concerned with participants' perceptions as to how they relate to the 
gazettal of a historic space as national heritage. To evaluate DA results, each participant's transcript together with the analytic interpretation, were sent to each participant involved for verification and agreeance.

\subsection{Results}

\subsection{The importance of designating Padang as the National Heritage}

From the interviews conducted, all participants positively agreed that it is important to conserve the Padang together with the surrounding heritage buildings as a whole place. For participants, this space acted as a pivot point for all National Heritage listed buildings because there are 10 listed heritage buildings located around this space. The key questions that arose amongst participants was "why is this space is not listed as the National Heritage and gazetted together with the [Independence] flag-post?" (GA2, GA3, GA4, KLLA4, PP1, PP2, PP3 and NG01). The main factors mentioned by participants, that linked a building to its environs, is historic context. It is evident that historic context is a very significant part of the connection between a building and its environs. As stated by one of the participants, "the history of a place is not only about the building ... but, the whole area. The whole area is the history" (PP1). Therefore, encompassing a building with its immediate surrounding as a whole is vital to understanding and narrating the cultural history of space and place; in this instance the Padang (Fig. 5).

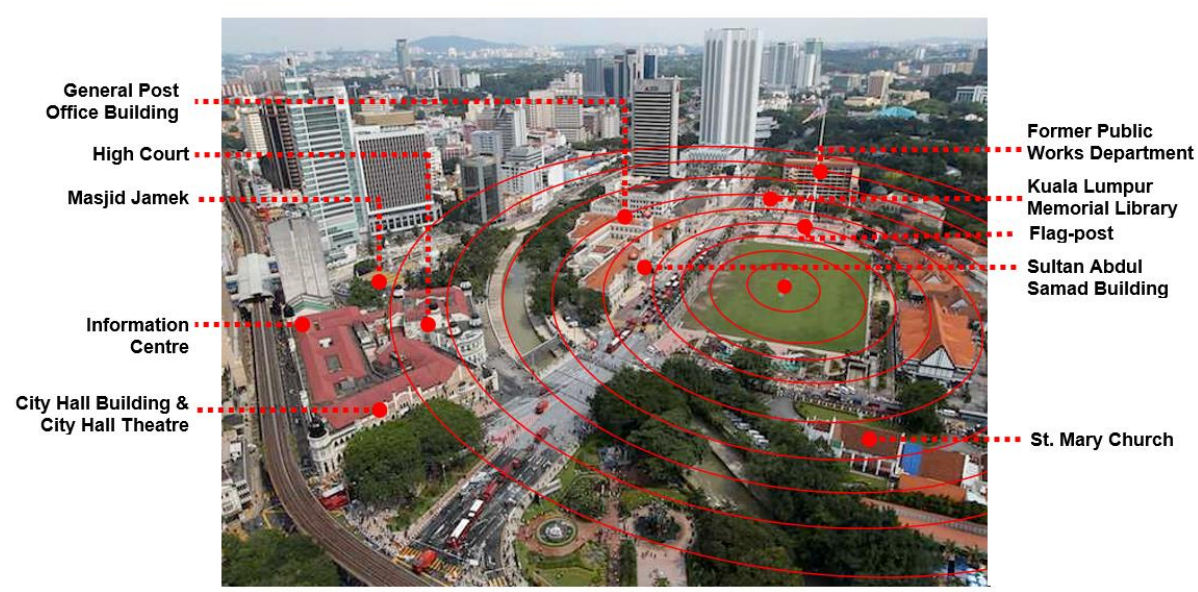

Fig. 5: Merdeka Square acts as a centre to other National Heritage Buildings in Kuala Lumpur (Source: (Nayan, 2017, p. 265). Image retrieved from The Malay Mail, 2012)

Most participants were very concerned about the future of the area because they observed that the majority of conservation works undertaken in Malaysia focused upon individual buildings and did not include historic spaces (GA2). Without holistic research and guidelines, "we might be destroying all the historical elements which give meanings to the 
building" (PP3). For participants, the implementation of a Special Area Plan was envisaged as being a more comprehensive approach because it involves an analysis of an area rather than an individual building (GA1, GA2, GA4, KLLA1, KLLA2, KLLA3, PP2, and PP3).

\subsection{The future of historical place designation in Malaysia}

Because of participants' understanding of 'heritage space' or 'historical area', the acceptance of a historic area concept being included inside current legislation is possible. Participants agreed that the designating process could be attained through thorough investigating, understanding and interpretation of the importance of the space. If there is no immediate action taken by the government, the participants were concerned that the future of this historic space will be threatened and compromised by unplanned or unsympathetic developments (GA1, GA2, GA3, KLLA1, KLLA3, PP1, and PP3). The difficulty is that there is no gazetted heritage space in Malaysia. As stated by one of the government officer participants, "the conservation works is only limited to the boundary of the building... not even the lot ... and this is what mostly practiced here" (GA2). As a result, a heritage space or area is often overlooked (NGO1). Hence, participants believed that the designating a historic area in Malaysia will possibly happen, but most conceded that it may take considerable time to occur. The policy makers group should, therefore, be advocated as to the collective conservation of historical space together with heritage buildings (GA3, PP2, PP3 and PP4). Thus, policies and Act amendments thereafter should be introduced to be more responsive to space conservation and to ensure easy implementability (PP2 and PP3).

\subsection{Discussion}

\subsection{Designating a historical place}

The history of Kuala Lumpur is not about its buildings. Kuala Lumpur's history comprises the spaces these buildings and the activities that once existed in the area. The Padang is the real 'set piece' of this cultural space mosaic. The Padang became the heart of Kuala Lumpur. It has existed since Kuala Lumpur appeared on maps. The Padang "still carried the marks of the community clustering that had in part underlain their production and, in turn, reinforced racial stereotyping by their profound differences" (King, 2008, p. 16). The extend of land around the Padang should be defined as the encompassing is part of the heritage significance. It is not only for conservation purposes but also to the sustainability of the culture for the community. The preservation of the setting will safeguard the cultural identity of the Padang. Therefore, culture and its environment cannot be separated, and both need to be conserved as a whole because both contribute to the significant value(s) of the area (Nayan, 2017, p. 63; Orbasli, 2008, p. 19). Only then will the values and the integrity of an area be conserved and protected. As highlighted by Rudduck (1955), "the sitting and architectural treatment of the principal governmental buildings, the landscaping of surrounding areas and their relationship to the planning of the reminder of the [Kuala Lumpur] town, are matters of the greatest importance" (Rudduck, 1955, p. 71).

\subsection{Implementing comprehensive laws in historical area conservation}


The importance of having comprehensive heritage legislation and accompanying guidelines is undeniable as the means to be able to protect vulnerable heritage spaces and buildings in Malaysia. Even though Act 645 is considered new, cooperation between all stakeholders could be garnered into drafting an integrated comprehensive set of guidelines and framework in conserving a national heritage space. The ideas of adopting ICOMOS's Charters for equivalent use in Malaysia would be a good start for appropriate conservation activities in the future. Considering the historical evolution of Padang and the feedback from the heritage practitioners, there is an urgency to designate heritage space in Malaysia (Nayan \& Jones, 2011, p. 34).

\subsection{Conclusion}

For the Padang, the level of appreciation of this space and its important continuity of use today has protected it from development intrusion. However, without any particular regulations, this site might also be threatened like other spaces. It is important to at least include this space on a local authority heritage list to ensure that this space can be protected for future generations. The Padang is an example of an area that symbolizes the "a plethora of places where mixing of the races and even of the social classes" once did and still occurs in Kuala Lumpur (King, 2008, p. xxv).

Protecting the Padang is equally important as protecting the history of Kuala Lumpur. Hence, further research is needed to identify appropriate mechanisms and criteria in safeguarding a historical space. Involvement of stakeholders and conservators in a focus group discussion can be implemented to obtain a better understanding and possible solutions for protecting a historical space, especially in an urban landscape.

\section{References}

Australian Heritage Commission. (2000). Protecting Heritage Places. Canberra: Australian Government Retrieved from http://155.187.2.69/heritage/ahc/publications/commission/books/protecting-places/step4-01.html.

Bachek, S. H., Zainudin, H., \& Haron, N. A. (2014). Preservation of culture and built heritage in new urban development: A case study on Little India Brickfields, Kuala Lumpur. Paper presented at the International Conference on Humanity, History and Society, Penang, Malaysia.

Draft Kuala Lumpur City Plan 2020 (DKLCP2020), (2008a).

Draft Kuala Lumpur City Plan 2020 (DKLCP2020), (2008b).

Environment Foundation. (2017). What is Historic Heritage? Retrieved from http://www.environmentguide.org.nz/issues/heritage/what-is-historic-heritage/

Gholitabar, S., Alipour, H., \& Costa, C. M. M. d. (2018). An empirical investigation of architectural heritage management implications for tourism: The case of Portugal. Sustainability, 10(93), 1-32. doi:10.3390/su10010093

Google Maps. (2019). Merdeka Square: Google Maps. 
Gullick, J. M. (1998). Old Kuala Lumpur. Selangor, Malaysia: Penerbit Fajar Bakti Sdn. Bhd.

Gullick, J. M. (2007). Selections from the Selangor Journal. Selangor: The Malaysian Branch of the Royal Asiatic Society.

Historic England. (2015). Managing change to significant places. Conservation Principles, Policies and Guidance. London: English Heritage.

King, R. (2008). Kuala Lumpur and Putrajaya: Negotiating urban space in Malaysia. Singapore: NUS Press.

Kuala Lumpur Structure Plan 2020 (KLSP2020), (2000).

Lubis, A.-R. (2018). Sutan Puasa: Founder of Kuala Lumpur. Kuala Lumpur: Areca Books.

Mason, J. (2002). Qualitative researching (Second ed.). London: SAGE Publications, Inc.

National Heritage Act 2005 (Act 645), (2005).

Nayan, N. M., \& Jones, D. S. (2011). Conserving the Heritage Spaces of Kuala Lumpur: A Case Study of the Old Market Square (Medan Pasar). In S. Mohd, A. Azman, J. Sulaiman, \& J. L. Fernandez (Eds.), Multifacted Aspects of Asian Heritage (pp. 33-42). Penang, Malaysia: School of Social Sciences, Universiti Sains Malaysia.

Nayan, N. M. (2017). Conservation of heritage curtilages in Kuala Lumpur Malaysia. (PhD), The University of Adelaide, Adelaide.

Nayan, N. M., Khamis, M. K., Sakip, S. R. M., \& Rahman, N. A. (2018). Sydney Lake: The historical park of KL. Asian Journal of Quality of Life, 3(10), 149-158. doi:https://doi.org/10.21834/ajqol.v3i10.111

Nui, C. K. (1997). From poor migrant to millionaire (Chan Wing: 1873 - 1947). Kuala Lumpur: Malaysian Branch of the Royal Asiatic Society

Orbasli, A. (2008). Architectural Conservation: Principles and practice. Oxford: Blackwell Publishing.

Rudduck, G. (1955). Town planning in Kuala Lumpur. Kuala Lumpur: United Nations Technical Assistance Administration.

Silverman, D. (2014). Interpreting qualitative data (Fifth ed.). Los Angeles: SAGE Publications Ltd.

Southgate, A., \& Bracken, G. B. (2014). A Walking Tour Kuala Lumpur: Journey through Kuala Lumpur's urban landscape. Singapore: Marshall Cavendish International (Asia) Pte Ltd.

The Kuala Lumpur Municipal Council. (1959). Centenary 1859 - 1959: Kuala Lumpur 100 years. Kuala Lumpur: The Kuala Lumpur Municipal Council.

Yeang, K. (1992). The architecture of Malaysia. Amsterdam: The Pepin Press. 